\title{
Are promising mechanisms of hydroxychloroquine abolish COVID-19 activity? A review study
}

\author{
Y.J. Mousa ${ }^{1}$, M.B. Mahmood ${ }^{2}$, F.A. Isihak ${ }^{3}$ and A.A. Mohammed ${ }^{4}$ \\ ${ }^{1}$ Department of Physiology, Biochemistry and Pharmacology, ${ }^{3}$ Department of Microbiology, College of Veterinary Medicine, \\ University of Mosul, Mosul, ${ }^{2}$ Department of Internal Medicine, Surgery and Pharmacology, College of Veterinary Medicine, \\ ${ }^{4}$ Department of Pharmacology and Clinical Pharmacy, College of Pharmacy, University of Dohuk, Dohuk, Iraq \\ Email: ${ }^{1}$ yarub204@uomosul.edu.iq, ${ }^{2}$ mahmood.basher@uod.ac, ${ }^{3}$ fanar1976@uomosul.edu.iq, \\ ${ }^{4}$ ammar.brifkani@manchester.ac.uk
}

(Received May 5, 2020; Accepted May 23, 2020; Available online June 12, 2020)

\begin{abstract}
To explore the benefits of Hydroxychloroquine (HCQ), (which is an antimalarial agent that has shown effective pharmacological properties in different malarial conditions and immunological disorders, particularity in chloroquine-sensitive malaria), in the treatment and prevention of Corona Virus Disease-2019 (COVID-19) pandemic because HCQ was recently advocated to minimize the pathogenicity of COVID-19. The aim of this review is to shed the light on a possible mechanism by which HCQ can defeat the COVID-19, a disease characterized by the WHO as a pandemic. Literatures from Web of Science, Scopus, PubMed, Science Direct and Google Scholar were cast-off to search the literature data. The keywords used are antimalarial agent, COVID-19, Hydroxychloroquine, SARS-CoV-2 and Zinc sulfate. The review summarizes the benefits of using HCQ against COVID-19 through exploiting the ability of this antimalarial agent in ameliorating the body immunity, inhibiting and/or delaying the viral glycosylation by increasing the $\mathrm{pH}$ inside the host cell and also via suppressing the viral transcription and replication through the formation of a complex structure after binding with zinc. We concluded that these interfering properties of HCQ support human immunity to fight against the progression of COVID-19. We hypothesize that the therapeutic efficiency of HCQ against the COVID-19 can be enhanced by the concurrent administration of zinc sulfate.
\end{abstract}

Keywords: Antimalarial agent, COVID-19, Hydroxychloroquine, SARS-CoV-2, Zinc sulfate

DOI: 10.33899/ijvs.2020.127049.1449, (@2020, College of Veterinary Medicine, University of Mosul.

This is an open access article under the CC BY 4.0 license (http://creativecommons.org/licenses/by/4.0/).

$$
\begin{aligned}
& \text { هل آليات العمل الواعدة للهيدروكسي كلوروكوين تلفي نشاط الكوفيلـ9 ا؟؛: دراسة مراجعة } \\
& \text { يعرب جعفر موسى'، محمود بشير محمود'، فنار أبلحد إسحقَّ و عمار أحمد محمد؛ }
\end{aligned}
$$

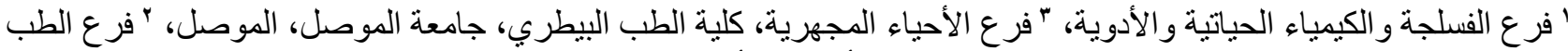

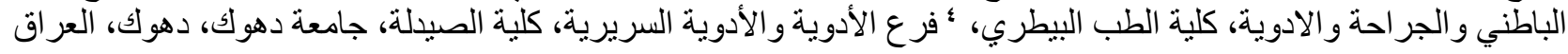

الخلاصة

تم اجر اء هذه المر اجعة الموضوعية لاستكثاف وتسليط الضوء على فولى فوائد واليات عمل الهيدروكسي كلوروكوين (وهو من الادوية

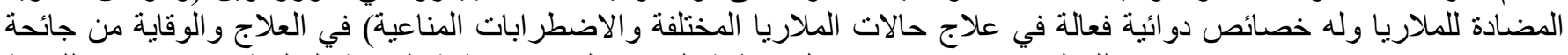

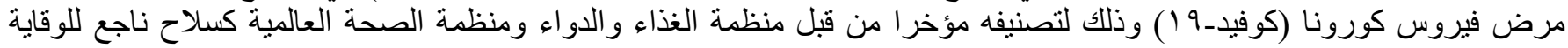

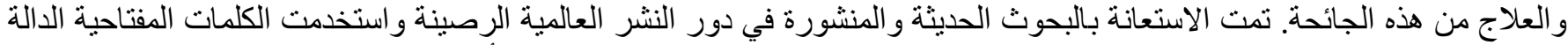

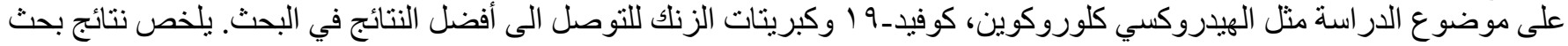

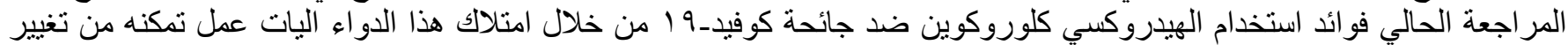
مناعة الجسم عن طريق تثيط/تأخير عملية تكاثر فايروس كوفيدي-19 (الكلايكوسيليشن)، زيادة فئن الأس الهيدروجيني داخل الخلية المضيفة 


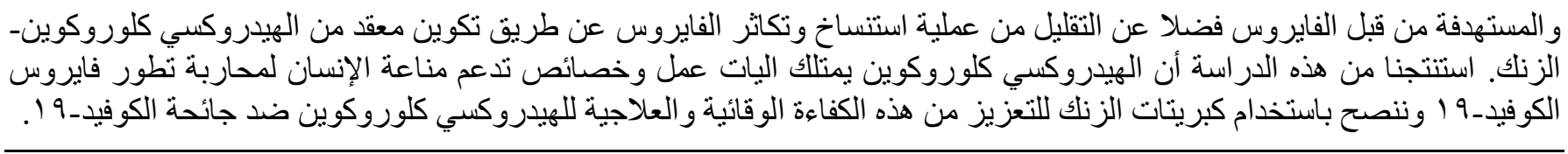

\section{Introduction}

HCQ is classified as one of therapeutic agents that are used to treat and reduce the severity of malarial conditions, particularly in chloroquine-sensitive malaria (1). In addition, HCQ has exhibited its effectiveness in the treatment of certain immunological disorders, such as rheumatoid arthritis, lupus erythromatosus and porphyria cutanea tarda (1). Recently, HCQ was recommended for the treatment of COVID-19 due to its ability in minimizing the pathological reactions associated with this viral infection (2). Now, the drug has been incorporated in the therapeutic protocol of COVID-19 in the hospitalized patients in several countries, including Iraq. In these patients, HCQ has shown approximately $50 \%$ increase in the recovery rate in response to the total active cases. In this review, we discuss the mechanism of action of HCQ that enables the drug to inhibit the COVID-19 activity against the host cells. However, using this medication is associated with certain adverse reactions which are not considered in this review, and therefore, careful management is required with this therapeutic intervention especially for those of cardiopulmonary involvement.

\section{Hypothesis of Antiviral action of HCQ for defeating COVID-19}

Many hypothetical mechanisms of antiviral action of HCQ against COVID-19 have been proposed. Firstly, when the infectious virus particle invades the target cell, by binding to Angiotensin-Converting Enzyme-2 (ACE-2) receptors on the pulmonary cell surface (3). The HCQ can decrease the glycosylation process of these receptors thereby blocking COVID-19 from effectively binding with these receptors (4). Secondly, an increase the endosomal and lysosomal acidification which inhibit the attachment of the virus with susceptible host cells and consequent process $(5,6)$. Thirdly, prevention of antigen processing and expression by Antigen Presenting Cells (APC) via MHC class II by reducing $\mathrm{T}$ cells activation and other cytokines production Interleukin (IL)-1, IL-6 and Tumor Necrosis Factor (TNF- $\alpha$ ) and fourthly, by inhibiting of the cytosolic interaction between viral DNA/RNA with Toll like receptors signals and the nucleic acid sensor through impairment of genes transcription pathways to proinflammatory cytokines which are responsible for creation of many cytokines that consequently leads to acute respiratory distress syndrome (ARDS) as a result of cytokines storm (7). Thus, HCQ has been suggested as a candidate for antiviral chemoprophylaxis against the recent pandemic with a novel SARS CoV-2. Lastly, the chemical structure of chloroquine (CQ) and HCQ are 4aminoquinoline derivatives (Figure 1) and have a benefit in competing with the porphyrin and binding to the viral protein, thereby reducing the viral protein's attacking the heme or binding to the porphyrin and effectively relieve the symptoms of respiratory distress (8).
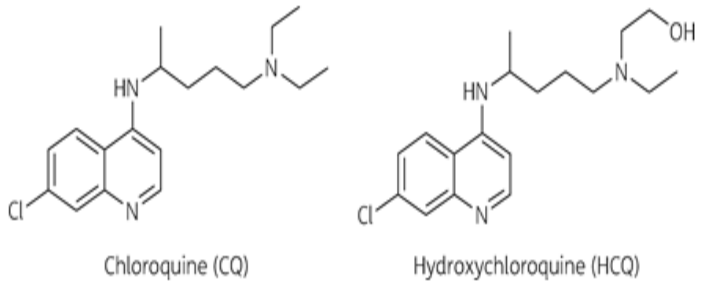

Figure 1: The chemical structures of CQ and HCQ (8)

\section{Lysosomal enzymes}

The mammalian cells possess lysosomes, which are viable and important organelles that secrete certain enzymes including the acidic hydrolase. These lysosomal enzymes have a reliable efficacy in an acidic environment of a $\mathrm{pH}$ range of 4.5-5 and their function is compromised with any alteration of this acidity $(9,10)$. These lysosomal enzymes enhance the degradation of biological polymers, such as proteins, nucleic acids, carbohydrates and lipids $(9,10)$. It is essential to understand the mechanical activity of lysosomal enzymes, which can be exploited by the HCQ to ameliorate the pathogenesis of COVID-19 as this step is an important milestone in the glycosylation process. Up to this moment there is insufficient understanding of the reality of the COVID-19, and no vaccine. HCQ may be play important agent to treat the patients with severe symptoms.

\section{The structure and pathogenicity of COVID-19}

It is essential to understand the structure activity relationship and the pathogenicity of COVID-19 (Figure 2). This helps in assessing the effectiveness of HCQ in the treatment of this pandemic disease. Basically, the COVID19 belongs to the RNA type of the coronavirus family, the envelope is bilayer of lipid membrane acquired through budding from the cytoplasmic membranes, the size range from $120-140 \mathrm{~nm}$ in diameter (11). The RNA is surrounded 
by a protective glycoprotein membrane layer (envelope protein) containing a glycoprotein spike (12). At the beginning, the COVID-19 enters the target host cells (Pulmonary cells) and starts to replicate. This replication involves multiple stages starting from the phagocytosis through the viral binding to ACE-2 receptors until the end of replication. Glycosylation is an intermediate stage in the process of replication, where the glycoprotein viral layer of COVID-19 loses its outer spikes by the effect of lysosomal enzymes at a pH-dependent manner $(10,11)$.

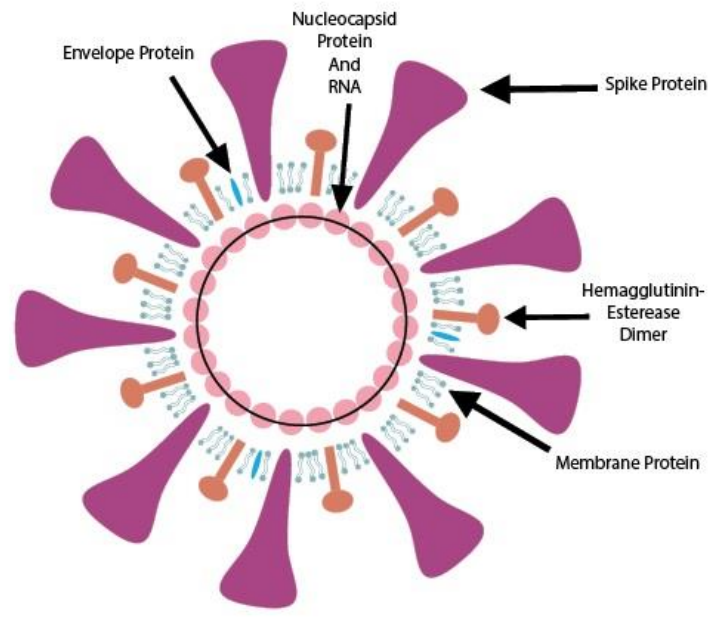

Figure 2: COVID-19 structure (12).

\section{The effect of HCQ chemical structure on viral glycosylation}

Studies showed the chemical structure of HCQ (Figure 1) composed of a carbon atom (C-18) and a functioning group of three amino- and one hydroxyl-group. These groups have the ability to form hydrogen bonds, which are responsible for the highly distribution of the drug to various parts of the human body. These bonds also increase the absorption and solubility of the drug inside the body and prolong both, the excretion and persistence (35-40 days) times $(13,14)$.

Since HCQ has high lipid solubility, it can reach different body organs and cells, and thus, it increases the $\mathrm{pH}$ of the cells, which consequently leads to the inhibition of the lysosomal enzymes involved in the glycosylation, and thereafter, delaying the release of viral content (RNA) into the host cells (15).

\section{The activity of HCQ-Zn complex against the viral replication}

Zinc $\left(\mathrm{Zn}^{+2}\right)$ and vitamins can raise the immunity of the patient during recovery from disease. The formation of the complex via the presence of pair of electrons on $\mathrm{N}$ atom of the amino and $\mathrm{O}$ atom of the hydroxyl groups, this HCQ$\mathrm{Zn}^{+2}$ complex known 1:1 complex as shown in (Figure 3). This complex has shown an antioxidant activity and has also exerted an essential role against the viral invasion and replication (16-18). Moreover, the activity of $\mathrm{Zn}$ against COVID-19 is considered to be due to its ability to inhibit the RNA-Dependent RNA Polymerase, an enzyme responsible for the formation of viral RNA, and therefore, it reduces the viral replication and minimizes the virulence of COVID-19 (19-21).

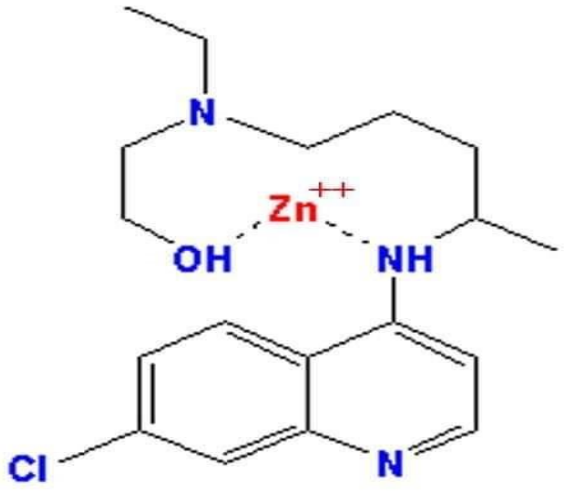

Figure 3: The proposed chemical structure of HCQ- $\mathrm{Zn}^{+2}$ complex (16).

\section{HCQ involvement in the Cytokines storm}

HCQ has an anti-inflammatory role by inhibiting the production of three important mediators of inflammation, TNF- $\alpha$, IL-1 and IL-6 (22). Monoclonal antibodies directed against amplified immune response caused by cytokines (IL-6) in the lung and other organs in COVID-19 infection, and showed good results in sever COVID-19 pneumonia. These are also responsible for initiating the inflammatory process that will end with vasodilation and increased vascular permeability to allow for attraction of white blood cells to the site of infection and enter into the affected tissue. Macrophages that enter into the tissue, and release all types of mediators, that cause injury to both the virus and our own cells (23) thus tissue damage inflammation with induction of autoimmune response (24). Therefore, HCQ has an important role in preventing of cytokine storm, which is when there are so many immune mediators being released at once to fight an infection that the host itself is overwhelmed and dies (25). The cytokine storms have been implicated in the death of COVID-19 patients.

\section{A brief summary of some clinical trials associated with HCQ treatment against COVID-19}

More than 92 clinical trials in the world during this period for different treatments single drug, combination therapy or vaccines referring to the HQC trial of 62 patients 
with mild infection by COVID-19 associated with pneumonia revealed that the body temperature retrieval and the cough retardation time were significantly decrease with HCQ 400mg/day $(200 \mathrm{mg} / \mathrm{bid})$ treated patients and improvement of pneumonic signs (80.6\%, compared with the control patients $54.8 \%$ (26). Other trial in China of 20 treated patients with HCQ in comparison with 16 untreated patients in France concluded that HCQ was effective in viral load reduction (27). A study performed in Marseille, France showed that HCQ alone or in a combination with azithromycin was effective and significant in clearing of nasopharyngeal samples measured by PCR after 3-6 days in COVID-19 patients compared to control and the viral clearance with HCQ at day-6 post-inclusion was $70.0 \%$ against $12.5 \%$ in control group (28). The vaccines are most important tool to combat COVID-19 but it need time, cost and approval from FDA. Now, the clinical trials try to evaluate the safety and the potency of HCQ because it is well-known drug, ecumenically cheap and available in most counties.

\section{Conclusion}

The present review can conclude that HCQ possesses certain properties that support its effectiveness against the COVID-19. These include decrease of COVID-19 binding to ACE-2 receptors, amelioration of body immunity, its ability to inhibit and/or delay the viral glycosylation process, reducing the cytokine storm and its activity in suppressing the viral transcription and replication by the formation of the HCQ- $\mathrm{Zn}^{+2}$ complex. These abilities may regulate the body immunity to fight and abolish the progression of COVID-19. We strongly recommend the concurrent administration of Zinc sulfate with HCQ in the therapeutic protocol for further preventive efficacy against COVID-19 pandemic.

\section{Acknowledgments}

Many thanks to the Universities of Mosul and Dohuk for providing facilities and support needed.

\section{Conflict of Interest}

The authors declare that have no conflict of interests.

\section{References}

1. D'Alessandro S, Scaccabarozzi D, Signorini L, Perego F, Ilboudo DP, Ferrante P, Delbue S. The use of antimalarial drugs against viral infection. Microorg. 2020;8(1):85. DOI: 10.3390/microorganisms 8010085

2. Cortegiani A, Ingoglia G, Ippolito M, Giarratano M, Einav S. A systematic review on the efficacy and safety of chloroquine for the treatment of COVID-19. J Crit Care. 2020;57:279-283. DOI: $10.1016 /$ j.jcrc.2020.03.005
3. Zhou P, Yang XL, Wang XG, Hu B, Zhang L, Zhang W, Si H-R, Zhu Y, Li B, Huang CL, Chen HD, Chen J, Luo Y, Guo H, Jiang RD, Liu MQ, Chen Y, Shen XR, Wang X, Zheng XS, Zhao K, Chen QJ, Deng F, Liu LL, Yan B, Zhan FX, Wang YY, Xiao GF, Shi ZL. A pneumonia outbreak associated with a new coronavirus of probable bat origin. Nature. 2020;579(7798):270-273. DOI: 10.1038/s41586020-2012-7

4. Devaux CA, Rolain JM, Colson P, Raoult D. New insights on the antiviral effects of chloroquine against coronavirus: What to expect for COVID-19?. Inter J Antimicrob Agents. 2020;55(5):105938. DOI: 10.1016/j.ijantimicag.2020.105938

5. Chakraborti S, Prabakaran P, Xiao X, Dimitrov DS. The SARS coronavirus $\mathrm{s}$ glycoprotein receptor binding domain: Fine mapping and functional characterization. Virol J. 2005;2:73. DOI: 10.1186/1743-422X-2-73

6. Watanabe Y, Berndsen ZT, Raghwani J, Seabright GE, Allen JD, McLellan JS, Wilson IA, Bowden TA, Ward AB, Crispin M. Vulnerabilities in coronavirus glycan shields despite extensive glycosylation. Nature Commun. 2020;11:2688. DOI: 10.1038/s41467-020-16567-0

7. Savarino A, Boelaert JR, Cassone A, Majori G, Cauda R. Effects of chloroquine on viral infections: An old drug against today's diseases. Lancet Infec Dis. 2003;3(11):722-727. DOI: 10.1016/s14733099(03)00806-5

8. Roldan EQ, Biasiotto G, Magro P, Zanella I. The possible mechanisms of action of 4-aminoquinolines (chloroquine/hydroxychloroquine) against Sars-Cov-2 infection (COVID-19): A role for iron homeostasis? Pharmacol Res. 2020;13:104904. DOI: 10.1016/j.phrs.2020.104904

9. Mindell JA. Lysosomal Acidification Mechanisms. Annu Rev Physiol. 2012;74:69-86. DOI: 10.1146/annurev-physiol-012110-142317

10. Kallunki T, Olsen OD, Jaattela M. Cancer-associated lysosomal changes: Friends or foes?. Oncogene. 2013;32:1995-2004. DOI: 10.1038/onc.2012.292

11. Shereen MA, Khan S, Kazmi A, Bashir N, Siddique R. COVID-19 infection: Origin, transmission, and characteristics of human $\begin{array}{lll}\text { coronaviruses. J Adv Res. 2020;24:91-98. DOI: } & \end{array}$ 10.1016/j.jare.2020.03.005

12. Fehr AR, Perlman S. Coronaviruses: an overview of their replication and pathogenesis. Methods Mol Biol. 2015;1282:1-23. DOI: 10.1007/978-1-4939-2438-7_1

13. Deroco PB, Vicentini FC, Oliveira GG, Rocha-Filho RC, FatibelloFilho O. Square-wave voltammetric determination of hydroxychloroquine in pharmaceutical and synthetic urine samples using a cathodically pretreated boron-doped diamond electrode. J Electroanaly Chem. 2014;719:19-23. DOI: 10.1016/j.jelechem.2014.01.037

14. Browning DJ. Pharmacology of Chloroquine and Hydroxychloroquine. Hydroxychloroq Chloroq Retinop. 2014;4:3563. DOI: 10.1007/978-1-4939-0597-3_2

15. Wang Y, Shi K, Zhang L, Hu G, Wan J, Tang J, Yin S, Duan J, Qin M, Wang N, Xie D, Gao X, Gao H, Zhang Z, He Q. Significantly enhanced tumor cellular and lysosomal hydroxychloroquine delivery by smart liposomes for optimal autophagy inhibition and improved antitumor efficiency with liposomal doxorubicin. Autophagy. 2016;12:949-962. DOI: 10.1080/15548627.2016.1162930

16. Navarro M, Hernandez C, Va'squez F, Goitia H, Ojeda LE, Vela'squez M, Fraile G. Syntheses, characterization, and biological evaluation of new zinc-and gold-chloroquine diphosphate complexes. Trans Met Chem. 2008;33:893-898. DOI: 10.1007/s11243-008-91290

17. Xue J, Moyer A, Peng B, Wu J, Hannafon BN, Ding WQ. Chloroquine is a zinc ionophore. PLoS One. 2014;9:e109180. DOI: 10.1371/journal.pone.0109180

18. Abdulwahid AJ, Hassan AA. Effect of zinc sulphate and cadmium chloride on heat shock protein 70 and some sex hormones in adult male rabbits. Iraqi $J$ Vet Sci. 2018;32(2):29-35. DOI: $10.33899 /$ ijvs.2019.153874 
19. te Velthuis AJ, van den Worm SH, Sims AC, Baric RS, Snijder EJ, van Hemert MJ. $\mathrm{Zn}^{2+}$ inhibits coronavirus and arterivirus RNA polymerase activity in vitro and zinc ionophores block the replication of these viruses in cell culture. PLoS Pathogens. 2010;6:e1001176. DOI: 10.1371/journal.ppat.1001176

20. Kaushik N, Subramani C, Anang S, Muthumohan R, Shalimar, Nayak B, Ranjith-Kumar CT, Surjit M. Zinc salts block hepatitis e virus replication by inhibiting the activity of viral RNA-dependent RNA polymerase. J Virol. 2017;91:e00754-17. DOI: 10.1128/JVI.00754-17

21. Kar M, Khan NA, Panwar A, Bais SS, Basak S, Goel R, Sopory S, Medigeshi GR. Zinc chelation specifically inhibits early stages of dengue virus replication by activation of NF- $\mathrm{\kappa B}$ and induction of antiviral response in epithelial cells. Front Immunol. 2019;10:2347. DOI: 10.3389/fimmu.2019.02347

22. Sperber K, Quraishi H, Kalb TH, Panja A, Stecher V, Mayer L. Selective regulation of cytokine secretion by hydroxychloroquine: inhibition of interleukin 1 alpha (IL-1-alpha) and IL-6 in human monocytes and T cells. J Rheumatol. 1993;20(5):803-808.

23. Ben-Zvi I, Kivity S, Langevitz P, Shoenfeld Y. Hydroxychloroquine: From malaria to autoimmunity. Clin Rev Allerg Immunol. 2011;42(2):145-153. DOI: 10.1007/s12016-010-8243-x
24. Moudgil KD, Choubey D. Cytokines in autoimmunity: role in induction, regulation, and treatment. J Interferon Cytokine Res. 2011;31:695-703. DOI: 10.1089/jir.2011.0065

25. Singh AK, Singh A, Shaikh A, Singh R, Misra A. Chloroquine and hydroxychloroquine in the treatment of COVID-19 with or without diabetes: A systematic search and a narrative review with a special reference to India and other developing countries. Diab Met Syn: Clin Res Rev. 2020;14:241e246. DOI: 10.1016/j.dsx.2020.03.011

26. Jun C, Danping L, Li L, Ping L, QingFRevnian X, Lu X, Yun L, Dan H, Shuli S, Dandan Z, Zhiping Q, Tao L, Yinzhong S, Hongzhou L. A pilot study of hydroxychloroquine in treatment of patients with moderate COVID-19. J Zhejiang Univ. 2020;49(2):215-219. DOI: 10.3785/j.issn.1008-9292.2020.03.03

27. Sinha N, Balayla G. Hydroxychloroquine and COVID-19. Postgrad Med J. 2020;0:1-6. DOI: 10.1136/postgradmedj-2020-137785

28. Gautret P, Lagiera JC, Parolaa P, Hoanga VT, Meddeba L, Mailhea M, Doudier B, Courjon J, Giordanengo V, Vieira VE, Dupont HT, Honoré S, Colson P, Chabrière E, La Scola B, Rolain JM, Brouqui P, Raoult D. Hydroxychloroquine and azithromycin as a treatment of COVID-19: Results of open label non-randomized clinical trial. Int J Antimicrob Agents. $2020 ; 105949$.

DOI: 